\title{
EFFICIENCY OF OXYGEN - ABSORBING SACHETS IN DIFFERENT RELATIVE HUMIDITIES AND TEMPERATURES
}

\author{
Eficiência de absorvedores de oxigênio sob diferentes umidades relativas e temperaturas
}

\author{
Renato Souza Cruz ${ }^{1}$, Nilda de Fátima Ferreira Soares², Nélio José de Andrade ${ }^{3}$
}

\begin{abstract}
The main objective of this work was to evaluate the efficiency of oxygen - absorbing sachets at relative humidity of $75 \%, 80 \%$ and $85 \%$ and different temperatures, $10 \pm 2{ }^{\circ} \mathrm{C}$ and $25 \pm 2{ }^{\circ} \mathrm{C}$. The experiment consisted in determining the $\mathrm{O}_{2}$ absorption under these conditions. A sachet was placed in desiccators with an internal air homogenization system. Aliquots of air were removed at preestablished time intervals and analyzed for oxygen content. The results showed that oxygen absorption by the sachet increased as the relative humidity increased for both temperature. Therefore the oxygen - absorbing sachets were most active under $25 \pm 2^{\circ} \mathrm{C}$ and $85 \%$ relative humidity. At ambient condition $\left(25 \pm 2^{\circ} \mathrm{C} / 75 \% \mathrm{RH}\right)$ the rate of oxygen absorbed was $50 \mathrm{~mL} /$ day and $18,5 \mathrm{~mL} / \mathrm{day}$ for $10 \pm 2^{\circ} \mathrm{C}$. It was used a totally casualized design with three replicates.
\end{abstract}

Index terms: Active packaging, oxygen - absorbing, relative humidity, temperature.

\section{RESUMO}

O objetivo principal deste trabalho foi avaliar a eficiência de sachês absorvedores de oxigênio a $75 \%, 80 \%$ e $85 \%$ de umidade relativa e diferentes temperaturas, $10 \pm 2{ }^{\circ} \mathrm{C}$ e $25 \pm 2^{\circ} \mathrm{C}$. O experimento consiste em determinar a absorção de $\mathrm{O}_{2}$ sob essas condições. Um sachê foi colocado dentro de um dessecador contendo um sistema de homogeneização do ar interno. Alíquotas de ar são retiradas dos dessecadores em intervalos de tempos pré-estabelecido e seu conteúdo de oxigênio analisado. Os resultados mostraram que a absorção de oxigênio pelos saches aumentaram com o aumento da temperatura para ambas as temperaturas. No entanto, os sachês mostraram uma maior eficiência para $85 \%$ de umidade relativa e $25 \pm 2^{\circ} \mathrm{C}$ de temperatura. Na condição ambiente $\left(25 \pm 2^{\circ} \mathrm{C} / 75 \% \mathrm{RH}\right)$, a taxa de absorção dos sachês foi de $50 \mathrm{~mL} /$ dia e $18,5 \mathrm{~mL} /$ dia para $10 \pm 2^{\circ} \mathrm{C}$. O experimento foi conduzido com delineamento experimental inteiramente casualizado, com três repetições.

Termos para indexação: Embalagem ativa, sachês absorvedores de oxigênio, umidade relativa, temperatura.

(Received in december 21, 2005 and approved in october 3, 2006)

\section{INTRODUCTION}

The presence of oxygen $\left(\mathrm{O}_{2}\right)$ in packages is mainly due to failures in the packaging process, such as mixture of gases containing oxygen residues, inefficient vacuum as well as high rates of oxygen permeability through the packaging film utilized. Therefore, research and developments in the area of packaging have been conducted, aiming to eliminate residual $\mathrm{O}_{2}$. Within this context, the concept of active packaging was introduced. Such packaging interacts with the packaged product, modifying its properties in a desirable manner (ROONEY, 1995).

This new concept of packaging includes: oxygen and ethylene scavengers, carbon dioxide - scavengers and emitters, humidity and flavor controllers, films incorporated with antimicrobial and anti oxidant agents or displaying biodegradable properties (BERENZON \& SAGUY, 1998; HAN, 2002; VERMEIREN et al., 1999).

Overall, oxygen absorbing technology is based on oxidation or combination of one of the following components: iron powder, ascorbic acid, photosensitive polymers, enzymes, etc (FLOROS et al., 1997; LABUZA \& BREENE, 1989; ROONEY, 1995; VERMEIREN et al., 1999). These compounds are packaged into permeable material, usually in the form of sachets (ABE \& KONDOH, 1989; NAKAMURA \& HOSHINO, 1983). According to Abbott (2002) the main advantages in using absorbers are their ability to reduce the levels of oxygen to below $0.01 \%$, which is lower than the levels typically found $(0.3-3 \%)$ in the conventional systems of modified atmosphere, vacuum or substitution of internal atmosphere for inert gas. Thus, this method has attracted

\footnotetext{
Engenheiro de Alimentos, Professor, Doutor - Departamento de Tecnologia/DTEC - Universidade Estadual de Feira de Santana/UEFS - Km 03, BR 116, Norte, LABOTEC II - 44031-460 - Feira de Santana, BA - cruz.rs@gmail.com

2Engenheira de Alimentos, Professora, Doutora - Departamento de Tecnologia de Alimentos/DTA - Universidade Federal de Viçosa/UFV - Campus Universitário - 36570-000 - Viçosa, MG - nfsoares@ufv.br

${ }^{3}$ Engenheiro Agrônomo, Professor, Doutor - Departamento de Tecnologia de Alimentos/DTA - Campus Universitário - Universidade Federal de Viçosa/UFV - 36570-000 - Viçosa, MG - nandrade@ufv.br
} 
attention as a new packaging technology to preserve food that needs reduced levels of oxygen inside the packages (ABE \& KONDOH, 1989; NAKAMURA \& HOSHINO, 1983).

In order to obtain a greater absorbing effectiveness, some conditions must be met, such as, using containers or films providing a high oxygen barrier (oxygen-permeability rate of up to $20 \mathrm{~cm}^{3} / \mathrm{m}^{2}$.atm.day), films or recipients with good sealability. Another important parameter is selecting the appropriate absorber, i. e., type, size, capacity (NAKAMURA \& HOSHINO, 1983). Physical state, water activity in the food, the amount of oxygen dissolved in the product and the initial level of oxygen in package read space also must be taken into consideration (SMITH et al., 1990, 1995). When using absorbers in the form of sachets, a free air flow around the sachet is also needed, in order to enhance the oxygen-scavenging efficiency in the package (AZEREDO et al., 2000; SMITH et al., 1990, 1995). All these factors will contribute to the oxygen absorbers efficiency so that reduction of the oxygen level in the package could occur in a minimum time.

This work aimed to evaluate the absorption efficiency of a commercial oxygen absorbing system in the presence of different relative humidity levels, $75 \%, 80 \%$ and $85 \%$ and at $10 \pm^{\circ} \mathrm{C}$ and $25 \pm^{\circ} \mathrm{C}$.

\section{MATERIALAND METHODS}

The absorbing system used was sachet containing iron-based compounds O-Buster brand, FT-300 model, develop to be used in products with maximum water activity (Aw) of 0.85 . The absorption capacity of the sachet, according to the manufacturer, is of up to $300 \mathrm{~mL}$ of oxygen. The experiment was realized in entirely randomized design with three replicates.

\section{Determination of the absorption curve of sachets under different levels of relative humidity and temperatures}

The system used in the experiment consisted of 5.5 L capacity desiccators, each containing one absorbing sachet. The dessiccator lids contained silicone septa through which air samples were taken and analyzed by oxygen analyzer (MOCON). A ventilation system was installed inside each dessiccator, so that the air could be homogenized before being collected for analysis. The system was maintained hermetically sealed.

Relative humidity of 75,80 and $85 \%$ inside the desiccators was obtained, by using saturated solutions of sodium chloride, ammonium sulfate and potassium chloride, specific each one. Aliquots of $3 \mathrm{~mL}$ were collected for the experiment conducted at $25 \pm 2^{\circ} \mathrm{C}$ every 30 minutes, up to the first four hours and every four hours, afterwards. For the experiment under temperature of $25 \pm 2^{\circ} \mathrm{C}$, the intervals were every hour during the first 12 hours and every 12 hours, afterwards. Under both temperatures, the samples were collected until no oxygen absorption by the sachet was confirmed.

\section{RESULTS AND DISCUSSION}

Effect of relative humidity and temperature on the rate of oxygen absorption by use of sachets

Oxygen absorption by use of sachets is dependent on environmental factors, such as relative humidity and temperature. The results shown that the greater the relative humidity, the greater and faster the oxygen absorption by the sachet, for both storage temperatures. This fact is due to the need of the presence of water for the reaction between the oxygen molecule and the iron to occur. (Figures 1 and 2).

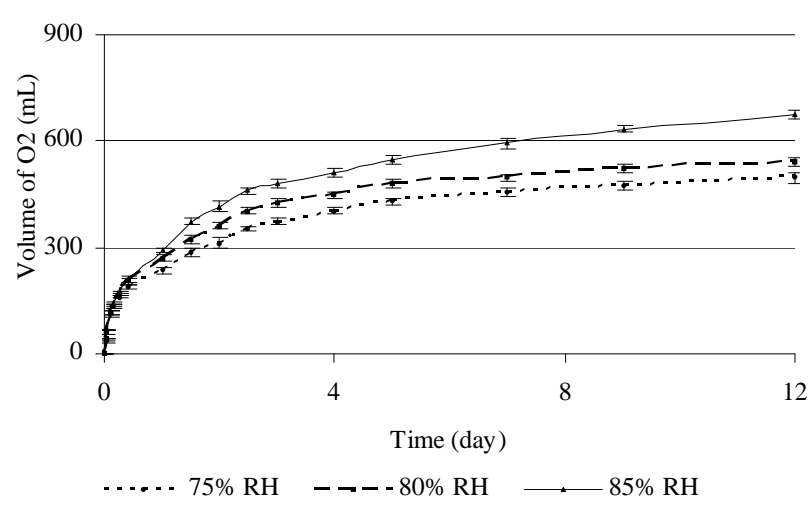

Figure 1 - Oxygen absorption by sachet at different rates of relative humidity at $25 \pm 2^{\circ} \mathrm{C}$, for a 12 -day period.

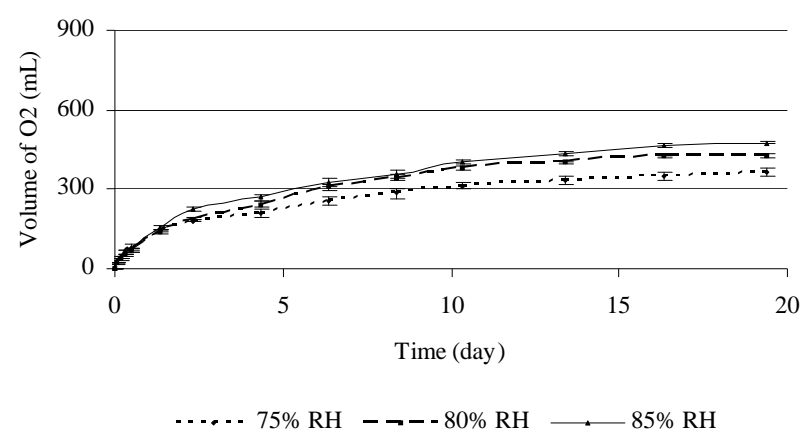

Figure 2 - Oxygen absorption by sachet at different rates of relative humidity at $10 \pm 2^{\circ} \mathrm{C}$, for a 19 -day period. 
The effect of relative humidity on the oxygen-iron reaction may be observed in the variation of activation energy (Ae) shown in Table 1, calculated by the Arrhenius equation $(\mathrm{Eq} \mathrm{I})$.

$\mathrm{K}=\mathrm{K}_{0} * \mathrm{e}^{\frac{-\mathrm{Ae}}{\mathrm{RT}}}$, Arrhenius equation, which through mathematical transformation, can be thus written:

$$
\operatorname{Ln}(K)=-\frac{A e}{R}\left(\frac{1}{T}\right)+c
$$

\section{where}

Ae - Activation energy

$\mathrm{R}$ - Constant of gases, 8,314 J/mol.K

$\mathrm{T}$ - Absolute temperature, Kelvin degree

$\mathrm{K}$ - Sachet absorption rate

Table 1 -Activation energy resulting from the iron-oxygen reaction for the different rates of relative humidity and temperature variation from $10 \pm 2^{\circ} \mathrm{C}$ to $25 \pm 2^{\circ} \mathrm{C}$.

\begin{tabular}{cc}
\hline Relative humidity $(\%)$ & $\mathrm{Ae}(\mathrm{KJ} / \mathrm{mol})$ \\
\hline 75 & $60.53 \pm 1.53^{\mathrm{a}}$ \\
80 & $60.09 \pm 1.14^{\mathrm{a}}$ \\
85 & $55.91 \pm 0.71^{\mathrm{b}}$ \\
\hline
\end{tabular}

Means followed by same letters do not differ significantly by the Tukey test $(\mathrm{p}<0,05)$.

The highest sachet absorption rate was found for relative humidity of $85 \%$, which, under this condition, presents lower activation energy, whose value was $55.91 \pm 0.71 \mathrm{KJ} / \mathrm{mol}$ (Table 1 ).

Temperature was also found to influence the rate of oxygen absorption by use of sachets. It should be emphasized that in both experiments, the amounts of oxygen absorbed, $420 \mathrm{~mL}$ and $570 \mathrm{~mL}$ for temperatures $10 \pm 2^{\circ} \mathrm{C}$ and $25 \pm 2^{\circ} \mathrm{C}$, respectively, were higher than $300 \mathrm{~mL}$, the amount indicated by the manufacturer. This value was reached for the experiment at $10 \pm 2^{\circ} \mathrm{C}$ around day 6 for humidity of 80 and $85 \%$, and around day 10 for humidity of $75 \%$. For the experiment at $25 \pm 2^{\circ} \mathrm{C}$, the amount indicated by the manufacturer was obtained after 24 hours for 80 and $85 \%$ of relative humidity and, around 36 hours for $75 \%$ of relative humidity.

The maximum amount of oxygen absorbed by use of sachet for the experiment at $10 \pm 2^{\circ} \mathrm{C}$ was lower than for the experiment at $25 \pm 2^{\circ} \mathrm{C}$ for all the relative humidity rates studied (Table 2). This can be explained by the fact that the absorbing system utilized absorbs oxygen through a chemical reaction, thereby being influenced by temperature, where at higher temperatures, the velocity of reaction is higher.

Table 2 - Maximum amount absorbed by use of sachet at different temperatures and relative humidity rates.

\begin{tabular}{ccc}
\hline $\begin{array}{c}\text { Relative } \\
\text { humidity (\%) }\end{array}$ & \multicolumn{2}{c}{ Maximum amount absorbed } \\
\hline & $10 \pm 2^{\circ} \mathrm{C}$ & $25 \pm 2^{\circ} \mathrm{C}$ \\
\cline { 2 - 3 } 75 & $363.13 \pm 8.72$ & $496.38 \pm 18.16$ \\
80 & $424.65 \pm 3.25$ & $540.28 \pm 29.12$ \\
85 & $474.96 \pm 1.8$ & $676.67 \pm 15.57$ \\
\hline
\end{tabular}

The volume of oxygen absorbed by the sachet decreases asymptotically along time, due to the irreversible reaction of iron to oxygen, which is available in excess (Figure 3 and 4). Another fact is the formation of a barrier by the ferrous particles nearest to the sachet walls that, when reacting, form a stable compound, iron hydroxide, hindering the contact of oxygen with the ferrous particles inside the sachet.

No considerable difference was observed in the absorption rate of the sachets stored at different relative humidity rates for both storage temperatures (Figures 5 and 6). However, such rate was influenced by temperature with values of $50 \mathrm{~mL} /$ day and $18,5 \mathrm{~mL} /$ day for temperatures of $25 \pm 2{ }^{\circ} \mathrm{C}$ and $10 \pm 2^{\circ} \mathrm{C}$, respectively.

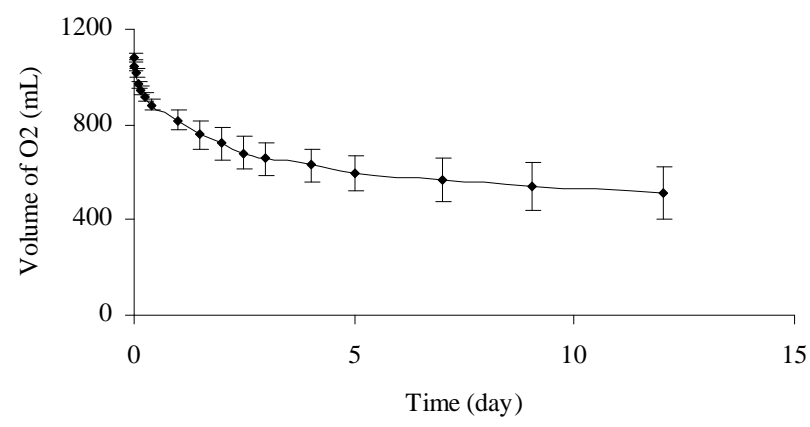

Figure 3 - Average of residual oxygen in the systems at different relative humidity, at $25 \pm 2^{\circ} \mathrm{C}$. 


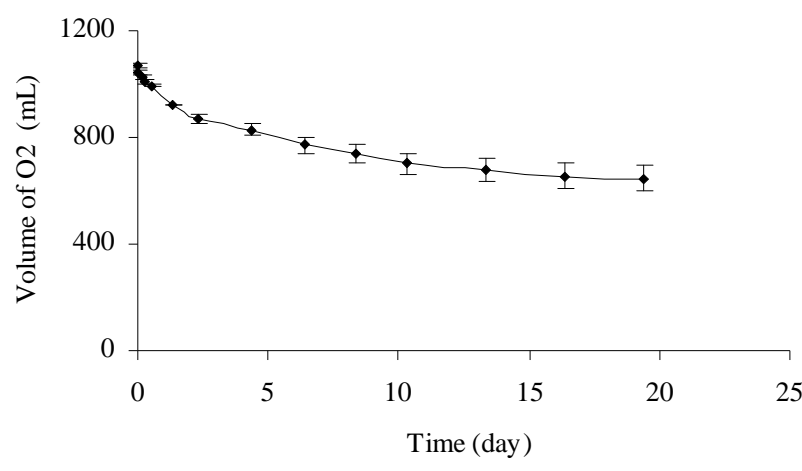

Figure 4 - Average of residual oxygen in the systems at different relative humidity rates, at $10 \pm 2^{\circ} \mathrm{C}$.

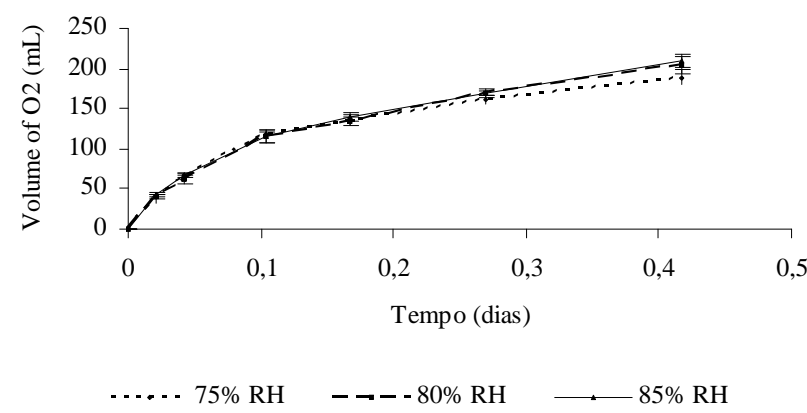

Figure 5 - Amount of oxygen absorbed in the first 12 hours at different relative humidity rates at $25 \pm 2^{\circ} \mathrm{C}$.

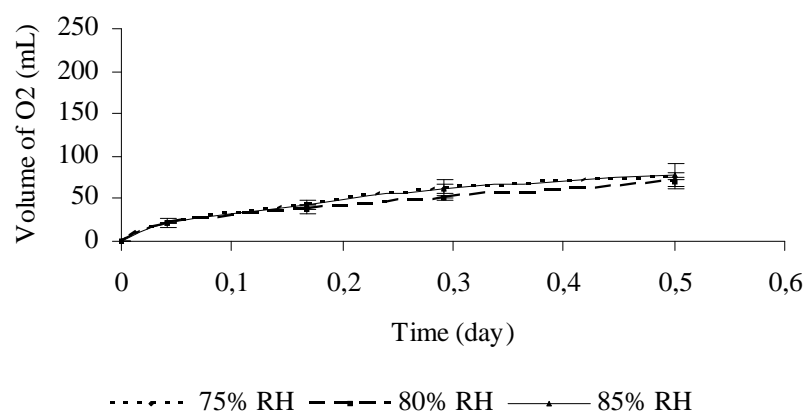

Figure 6 - Amount of oxygen absorbed in the first 12 hours, at different relative humidity rates at $10 \pm 2^{\circ} \mathrm{C}$.

This fact was likely due to the presence of agents such as silica or ascorbic acid (DELDUCA et al., 2001) which are incorporated into the sachet compounds, accelerating the reaction. At the first 12 hours the humidity present in the desiccator is enough to start the reaction.
After the different levels of relative humidity are reached, a differentiation in the absorption rates occurs according to the relative humidity rates. Temperature influenced the rate of oxygen absorbed by use of sachet in all the relative humidity values studied. Overall, a decrease of $57 \%$ was observed in the absorption rate by use of sachet as temperature decreased from $25 \pm 2^{\circ} \mathrm{C}$ to $10 \pm 2^{\circ} \mathrm{C}$.

The oxygen-absorbing sachets presented more activity at $25 \pm 2^{\circ} \mathrm{C}$ and $85 \%$ of relative humidity. The absorbers tested, FT-300 of O-Buster, showed a greater absorption capacity than that indicated by the manufacturer.

Under the average storage conditions in Brazil $\left(25 \pm 2^{\circ} \mathrm{C}\right.$ and $\left.75 \% \mathrm{RH}\right)$, the sachets presented absorption of approximately $500 \mathrm{~mL}$ of oxygen. At a temperature of $10 \pm 2^{\circ} \mathrm{C}$ and $75 \% \mathrm{RH}$ there was a reduction of $28 \%$, and a maximum of $\mathrm{O}_{2}$ absorption of approximately $360 \mathrm{~mL}$.

\section{CONCLUSION}

The oxygen-absorbing sachets presented more activity at $25 \pm 2^{\circ} \mathrm{C}$ and $85 \%$ of relative humidity, absorbing $650 \mathrm{~mL}$ of oxygen. When the typical Brazilian condition $25 \pm 2^{\circ} \mathrm{C}$ e $75 \% \mathrm{RH}$ presented absorption of approximately $500 \mathrm{~mL}$ of oxygen. In both cases, the amount absorbed by the sachet was higher than the manufacturer recommendation - $300 \mathrm{~mL}$. Therefore, the oxygenabsorbing sachets is an efficient device to remove oxygen from the interior of the packaging.

\section{ACKNOWLEDGEMENTS}

The financial support by CNPq, FAPEMIG and FINEP is gratefully acknowledged.

\section{REFERENCES}

AZEREDO, H. M. C.; FARIA, J. A. F.; AZEREDO, A. M. C. Embalagens ativas para alimentos. Ciência e Tecnologia de Alimentos, Campinas, v. 20, n. 3, 2000.

ABBOTT, R. Intelligent paper packaging of unwrapped. Disponible in: <http://www.piranet.com>. Accessed in: 10 Oct. 2002.

ABE, Y.; KONDOH, Y. Oxygen absorbers in CA/MA vacuum packaging of foods: food and nutrition, trumbull. Westport: [s.n.], 1989.

BERENZON, S.; SAGUY, I. S. Oxygen absorbers for extension of crackers shelf-life. Lebensmittel Wissenschaft und Technologie, Zurich, v. 31, p. 1-5, 1998. 
DELDUCA, G. R.; DEYO, A. E.; LUTHRA, V. K.; WU, W. P. Oxygen scavenger accelerator. US 6,315,921 B1. New York, 2001.

FLOROS, J. D.; DOCK, L. L.; HAN, J. H. Active packaging technologies and applications. Food Cosmetics and Drug Packaging, [S.1.], v. 10, n. 17, 1997.

HAN, J. H. Active food packaging. Disponible in: <http:// www.wmrc.com>. Accessed in: 10 Oct. 2002.

LABUZA, T. P.; BREENE, W. M. Applications of "active packaging" for improvement of shelf-life and nutritional quality of fresh and extended shelf-life foods. Journal of Food Processing and Preservation, Minessota, v. 13, n. 1, p. 1-69, 1989.

NAKAMURA, H.; HOSHINO, J. Technique for the preservation of food by employment of oxygen absorbers.
Tokyo: Technical Information Mitsubishi Gas Chemical, 1983.

ROONEY, M. L. Active food packaging. London: Blackie Academic and Profession, 1995. 280 p.

SMITH, J. P.; HOSHINO, J.; ABE, Y. Interactive packaging involving sachet technology. In: ROONEY, M. L. Active food packaging. London: Blackie Academic and Profession, 1995. p. 143-173.

SMITH, J. P.; RAMASWAMY, H. S.; SIMPSON, B. K. Development in food packaging technology: part 2: storage aspects. Trends of Food Science and Technology, Colney, v. 11, p. 111-118, 1990.

VERMEIREN, L.; DEVLIEGHERE, F.; BEEST, M. van; KRUIJF, N.; DEBEVERE, J. Development in the active packaging of foods. Trends in Food Science and Technology, Colney, v. 10, p. 77-86, 1999. 